\title{
The Effects of Performing Bridge Exercise and Hip Thrust Exercise using Various Knee Joint Angles on Trunk and Lower Body Muscle Activation in Healthy Subjects
}

\author{
Dongsu Kim ${ }^{a}$, Jongchan Junga ${ }^{\circledR}$, Yijung Chung ${ }^{\mathrm{b}} \oplus$ \\ aDepartment of Physical Therapy, The Graduate School, Sahmyook University, Seoul, Republic of Korea \\ ${ }^{\mathbf{b}}$ Department of Physical Therapy, College of Health and Welfare, Sahmyook University, Seoul, Republic of Korea
}

\begin{abstract}
Objective: This study aimed to identify the effects of assuming different knee angles and hip abduction during bridge exercise and
\end{abstract} hip thrust exercise on lower body muscle activity.

Design: Cross-sectional study

Methods: Thirty-three healthy adults ( 18 men and 15 women) were instructed to perform the bridge and hip thrust exercises while randomly assuming $120^{\circ}, 90^{\circ}$ and $60^{\circ}$ of knee flexion and $0^{\circ}$ and $30^{\circ}$ of hip abduction. EMG data (\%maximum voluntary isometric contraction) were recorded three times from the erector spinae (ES), gluteus maximus (GM) and biceps femoris (BF) muscles of participant's dominant side and the mean values were analyzed.

Results: The results showed that, during the hip thrust compared to the bridge exercise, there was significantly greater gluteus maximus muscle activity in all hip conditions while the biceps femoris activity was significantly less, and the erector spinae muscle activity was significantly greater with $30^{\circ}$ of hip abduction $(\mathrm{p}<0.05)$. With all exercises, the erector spinae and the biceps femoris exhibited significantly greater muscle activity with $60^{\circ}$ of knee flexion compared to $90^{\circ}$ and $120^{\circ}$ of knee flexion (p $<0.05$ ), and significantly greater muscle activity with $90^{\circ}$ compared to $120^{\circ}$ of knee flexion $(\mathrm{p}<0.05)$. In the case of the gluteus maximus, greater muscle activity was exhibited with $120^{\circ}$ compared to $60^{\circ}$ of knee flexion with all hip abduction conditions ( $\mathrm{p}$ $<0.05)$.

Conclusions: It was effective for muscle activation of main agonists such as the gluteus maximus and erector spinae during thrust exercise, and the change in knee flexion angle was effective for muscle activation of the gluteus maximus. Therefore, it is considered that this study can be used as a selective indicator of the target movement angle during hip strengthening exercise for specific muscles.

Key Words: EMG, Gluteus maximus, Hip thrust

서론

둔근의 근력을 향상시키는 것은 허리 재활과 부상 예방 활동에 있어 필수적이다[1]. 임상에서는 요통환자들의 재 활뿐만이 아니라 하지 질환 환자의 재활에서도 둔근 강화 의 중요성에 대하여 점점 강조되고 있다[2]. 둔근의 기능 장애는 요통과도 관련이 있을 뿐 아니라 다양한 하지 관 련 병리학적인 증상들과도 연관되어 있다[2]. 둔근 중에서
대표적인 고관절신전근(hip extensors)인 대둔근은 보행 초기 단계에서 기능적으로 움직임을 시작하는 역할을 하 고 있으며 하체를 지탱해주고 고관절과 무릎 그리고 발목 의 부상을 예방하는 역할을 하고 있다[3]. Sakamoto 등 [4]은 고관절신전근들의 작용 패턴 변화를 알아보기 위해 대둔근, 반건양근, 척추기립근의 근활성도를 네 가지 변형 된 운동 자세를 통해 알아보았는데, 운동 자세는 모두 엎 드린 자세에서 시행하였는데 무릎을 신전하고 고관절 신

Received: Jun 10, 2021 Revised: Jun 15, 2021 Accepted: Jun 16, 2021

Corresponding author: Yijung Chung (ORCID https://orcid.org/0000-0002-2431-8895)

Department of Physical Therapy, College of Health and Welfare, Sahmyook University

Hwarangro 815, Nowon-gu, Seoul, Republic of Korea [01795]

Tel: + 82-2-3399-1637 Fax: + 82-2-3399-1639 E-mail: yijung36@syu.ac.kr

This is an Open-Access article distributed under the terms of the Creative Commons Attribution Non-Commercial License (http://creativecommons.org/licenses/ by-nc/4.0) which permits unrestricted non-commercial use, distribution, and reproduction in any medium, provided the original work is properly cited.

Copyright @ 2021 Korean Academy of Physical Therapy Rehabilitation Science 
전, 무릎을 굴곡하고 고관절 신전, 고관전을 외측 회전한 상태로 무릎 신전 후 고관절 신전 마지막으로 고관절 외 측 회전한 상태로 무릎 굴곡 후 고관절 신전 실시하였다. 이 연구를 통해 고관절외회전 후 무릎 신전한 상태로 고 관절신전시켰을 때 가장 높은 근활성도를 보였으며 신전 근들의 작용 패턴은 모두 반건양근, 척추기립근 그리고 대둔근의 순서로 결과가 나타났다.

교각 운동에서 무릎 굴곡 각도 변화에 따른 하지 근육 들의 연구들도 이루어졌는데, 한발 교각 운동시 무릎을 $135^{\circ}$ 로 굽혔을 때 하지와 발과 지상 반응 힘 벡터(ground reaction force vector)와 평행을 이루면서 교각운동에서 필요한 슬괵근을 최소화하였다[5]. Hirose 등[6]은 교각 운동에서 무릎 굴곡 각도를 $30^{\circ}, 60^{\circ}, 90^{\circ}, 120^{\circ}$ 로 나누 어 대둔근, 반건양근, 척추 기립근의 근활성도를 확인하였 는데 그 결과 척추 기립근과 반건양근의 경우 굴곡 각도 가 $30^{\circ}$ 에서 가장 높은 근활성도를 나타내었으며, 대둔근 의 경우 무릎 굴곡 각도에 큰 차이를 나타내지 않았다.

추력운동(hip thrust)은 생체역학적으로 이 운동을 수행 하는 동안의 고관절의 가동 범위에서 큰 고관절 굴곡의 움직임을 만들어 낼 수 있기 때문에 대둔근 자극을 위한 효과적인 운동으로 소개되어 고관절 신전 속도를 증진시 킬 수 있으며, 체간의 수평력(horizontal force)을 생산할 수 있으며 대둔근의 근비대 효과를 불러 일으킬 수 있다 [3]. 추력 운동과 데드리프트(Deadlift) 운동 시에 대둔근 과슬괵근 그리고 척추기립근의 근활성도를 비교하였는데 그 결과 추력 운동에서 대둔근이 척추기립근보다 더 높은 근활성도를 나타냈다[3]. 추력 운동과 데드리프트 운동에 서 데드리프트의 고관절과 바벨간의 지렛대의 길이 차이 로 인해 대둔근과 슬괵근에서의 근활성도의 차이가 나타 났다[7]. 추력 운동이 데드리프트나 스쿼트보다 대둔근의 근활성도가 높은 것은 동작의 끝 범위가 크기 때문이다 [3]. 대둔근 굴곡 각도 범위가 클수록 대둔근의 높은 근활 성도를 보이며 대둔근 신전 마지막 동작 범위에서 최대치 근활성도를 나타낸다[8].

대둔근 강화에 대한 연구들은 주로 근전도를 이용하여 대둔근의 높은 근활성도를 보인 운동들을 순위로 나타내 는데 그쳤다[9]. 동시에 임상적으로 많이 사용되는 대둔근 강화 운동으로 교각 운동에 관한 연구가 소개되었으며, 교각 운동시 고관절을 $30^{\circ}$ 외전하였을 때 보다 높은 대둔 근의 근활성도를 나타내는 다양한 교각 운동에 관한 연구 가 이루어졌다[10]. 또한 대둔근 강화 운동에 효과적인 운 동으로 추력 운동이 소개되었으며[7]추력 운동이 척추 기 립근보다 대둔근에 효과적이라는 연구가 이루어졌다[3]. 하지만 추력 운동시 무릎 굴곡 각도 변화 및 고관절 외전 에 관한 연구가 이루어지지 않았다. 또한 추력 운동에 관 한 연구가 교각 운동에 비해 부족하고 임상에서 주로 사
용되는 교각 운동과 추력 운동 간의 차이를 비교한 연구 가 부족한 실정이다. 따라서 본 연구는 건강한 일반 성인 을 대상으로 두 개의 운동 간에 무릎의 각도 변화를 적용 하여 이러한 각도 변화가 체간과 둔부 근활성도에 미치는 영향을 알아봄으로써 보다 효과적인 대둔근 자극을 위한 향후 운동 처방의 기초 자료를 제시하고자 하였다.

\section{연구방법}

\section{연구대상}

본 연구는 건강한 성인들 중에서 대상자 선정기준에 부 합하는 33 명의 대상자를 선정하여 실험을 진행하였다. 실 험을 진행하기에 앞서 연구 대상자들에게 실험절차와 조 건에 대하여 설명한 후, 연구 참여 동의서를 읽고 동의하 여 동의서에 서명한 자를 대상으로 하였다.

대상자 선정기준은 지난 6 개월 동안 요통을 경험한 적 이 없는 성인으로 하였으며 대상자 제외기준은 심각한 척 추측만증이나 척추에 선천적 기형을 지닌 사람, 암이나 임신으로 운동을 수행이 불가능한 사람, 추간판탈출증과 같은 척추 질환이 있는 사람, 신경학적 질환 및 척추 수술 을 받은 이력이 있는 사람, 허리 혹은 복부에 통증이 있는 사람, 수술 혹은 외상으로 배에 상처 혹은 부상이 있는 사 람)으로 하였다. 또한 삼육대학교 연구윤리위원회의 승인 (2-7001793-AB-N-012019083HR)을 받은 후 진행하였다.

\section{연구절차}

\section{측정방법}

교각 운동과 추력 운동을 양발 간격 $25 \mathrm{~cm}$ 로 벌린 상 태에서 고관절 $0^{\circ}$ 외전한 상태와 $30^{\circ}$ 외전한 상태로 실시 하였으며 각 조건에서 무릎 각도 $60^{\circ}, 90^{\circ}, 120^{\circ}$ 굴곡한 상태에서 고관절을 들어 올리는 동작을 3 회씩 실시하여 근활성도를 측정하였다[7]. 각 조건 마다 근피로를 최소화 하기 위하여 동작 간 1 분간의 휴식을 취하게 하였다. 실 험 전 연구 대상자에게 교각운동과 추력 운동에 대하여 충분한 설명을 하였고 연구 대상자가 실험 동작을 충분히 숙지할 수 있도록 사전 연습 후 진행하였다.

교각 운동의 고관절 외전 $0^{\circ}$ 경우 상체는 지면에 위치 하고 하체의 고관절을 고정하고 양발의 간격을 $25 \mathrm{~cm}$ 로 벌린 상태로 지면으로부터 고관절이 $0^{\circ}$ 까지 들어 올려 무 릎 굴곡 각도를 각각 $60^{\circ}, 90^{\circ}, 120^{\circ}$ 인 상태에서 각각 5 초간 3회 반복한다[6]. 양발 간격과 무릎 각도를 각각 $60^{\circ}, 90^{\circ}, 120^{\circ}$ 변경 시 지면에 달라진 발 위치를 테이프 로 표시하여 실험자가 운동 시 해당 각도를 유지하게 시 행하였다. 교각 운동 고관절 외전 $30^{\circ}$ 경우 상체는 지면 
에 위치하고 하체의 양발 간격을 $25 \mathrm{~cm}$ 로 벌린 상태로 지면으로부터 고관절을 $0^{\circ}$ 까지 들어올렸을 때 고관절을 $30^{\circ}$ 외전 시킨 지점의 무릎 외측에 지지대를 설치하여 무 릎이 닿은 상태의 외전 각도를 유지하며 고관절을 오르내 리도록 하였으며 이 상태에서 무릎 굴곡 각도를 각각 $60^{\circ}, 90^{\circ}, 120^{\circ}$ 인 상태에서 각각 5 초간 3 회 반복하였다.

추력 운동은 높이 $45 \mathrm{~cm}$ 벤치 위에 대상자의 견갑대 상부를 위치시킨 뒤 고관절을 지면에 내려놓고 나머지는 교각 운동과 같은 방법으로 시행하였다. 측정 시 대상자 들은 실험자의 시작 음과 함께 5 초 동안 고관절을 들어 올리도록 하였고 이를 유지한 후 고관절을 천천히 내려 시작 각도로 돌아가도록 하였다. 이때 전 후 1 초간의 근 전도의 기록은 제외하였다. 고관절의 외전이 적용될 경우, 고관절 외전에 대한 가이드라인으로써 대상자의 상전장골 극 아래에 위치시킨 후 각 사지의 외전 각도에 대한 한계 점에 지지대를 세워 대상자가 외전 동작 시 한계에 벗어 나면 인지할 수 있도록 하였다[10]. 각각의 동작들은 난수 표를 이용하여 무작위 순서로 시행되었고 각 조건마다 3 회씩 측정하였다.

\section{측정 도구}

\section{근활성도}

각 동작에서의 근활성도를 측정하기 위해 표면근전도 (Telemyo $2400 \mathrm{G} 2$, Noraxon, U.S.A)를 사용하여 척추 기립근(Erector Spinae; ES), 대둔근(Gluteus Maximus; $\mathrm{GM})$, 대퇴이두근(Biceps Femoris; $\mathrm{BF}$ )의 근활성도를 측 정하였고 근전도 신호의 표본 추출률(sampling rate)은 $1500 \mathrm{~Hz}$ 로 설정하였고, 주파수 대역폭은 20-500 Hz로 하였다. 본 연구에서는 측정한 근육의 근전도 신호를 Myoresearch XP Master edition 소프트웨어(Noraxon Inc, Arizona, U.S.A)를 이용하여 정파정류(full wave rectification)로 처리한 후 $\mathrm{RMS}$ (root mean square) 250 $\mathrm{ms}$ 값을 취하였다. 전극의 부착 위치는 대둔근의 경우 두 번째 천추에서 대전자까지 거리의 $34 \%$ 의 거리에 근섬유 와 평행하도록 부착하였고 대퇴이두근의 경우좌골결절에 서 외측 슬와까지 거리의 $35 \%$ 의 지점에 근섬유와 평행하 도록 부착하였다[9]. 척추기립근의 경우 3 번 요추 극돌기 로부터 외측으로 $3 \mathrm{~cm}$ 정도 떨어진 위치에 근섬유와 평 행하도록 부착하였다[11]. 전극을 부착하기 전 털 있는 부 분을 제거하고 알코올 솜으로 부착부위를 깨끗이 닦아주 어 피부 저항을 최소화하였다. 모든 대상자들은 우세측 척추기립근, 대둔근 그리고 대퇴이두근에 전극을 부착한 후 각 근육의 $\mathrm{MVIC}$ 를 측정하였으며 각 근육의 측정 각 도는 도수근력 검사 각도(manual muscle test)를 기준으 로 시행하였다. 정규화방법은 각 5 초의 운동 중 움직임이
발생하는 앞뒤 1 초를 제외하고 정적인 상태의 가운데 3 초 구간을 추출한 근전도 신호를 $\mathrm{MVIC}$ 값으로 나누어 $\% \mathrm{MVIC}$ 값으로 정규화 하였다.

\section{자료분석}

본 연구의 모든 작업과 통계는 윈도우용 통계프로그램 SPSS(version 18.0, IBM Co., USA)을 이용하여 평균과 표준편차를 산출 하였으며 대상자의 일반적 특성은 기술 통계를 사용하였다. 고관절 각도 $0^{\circ}$ 와 $30^{\circ}$ 에서 교각운동 과 추력운동의 둔근 및 하지 근활성도에 미치는 영향을 비교하기 위해 무릎 $60^{\circ}, 90^{\circ}, 120^{\circ}$ 굴곡 상태의 3 가지 조건을 적용함에 따라 총 12 가지 동작에 대한 이원 반복 측정 분산분석(two-way repeated measures ANOVA)을 실시하였다. 최소유의차검증(least significant difference; $\mathrm{LSD})$ 을 이용해 사후 검증을 실시하였고, 모든 자료의 통 계학적 유의 수준은 $\mathrm{p}<0.05$ 로 하였다.

\section{연구 결과}

대상자는 총 33 명으로 남자 18 명, 여자 15 명, 평균 연 령은 34.06 세, 평균 신장은 $168.15 \mathrm{~cm}$, 체중은 $64.1 \mathrm{~kg}$ 이었다.

\section{척추기립근}

척추기립근의 근활성도고관절 $0^{\circ}$ 외전을 적용시, 무릎 자세의 주효과가 유의하였으나 $(\mathrm{F}=11.621, \mathrm{p}<0.05)$ 운동 종류의 주효과와 운동 종류와 및 무릎 자세변화의 상호작 용효과가 유의하지 않았다. 사후 분석 결과 근활성도는 무릎 각도 $60^{\circ}$ 굴곡이 $120^{\circ}, 90^{\circ}$ 굴곡보다 크게 나타났다 $(\mathrm{p}<0.05)$.

척추기립근의 근활성도고관절 $30^{\circ}$ 외전을 적용 시 교 각운동과 추력운동 차이에 따라 유의한 차이를 나타내었 으며 무릎 각도의 변화에 따라 유의한 차이를 나타내었다 $(\mathrm{F}=5.45, \mathrm{p}<0.05 ; \mathrm{F}=13.00, \mathrm{p}<0.05)$. 운동 종류와 무릎 각도 변화의 상호작용효과는 유의하지 않았다. 사후 분석 결과 근활성도는 무릎 각도 $60^{\circ}$ 굴곡이 $120^{\circ}, 90^{\circ}$ 굴곡 보다 유의하게 크게 나타났다 $(\mathrm{p}<0.05)$.

\section{대둔근}

대둔근의 근활성도고관절 $0^{\circ}$ 외전을 적용 시, 운동 종 류와 무릎 자세 변화의 주효과가 유의하였으나 $(\mathrm{F}=21.851$, $\mathrm{p}<0.05 ; \mathrm{F}=4.803, \mathrm{p}<0.05)$ 운동 종류와 무릎 자세 변화 의 상호작용효과가 유의하지 않았다. 사후 분석 결과 근 활성도는 무릎 각도 $120^{\circ}, 90^{\circ}$ 굴곡이 $60^{\circ}$ 굴곡보다 유의 
Table 1. Muscle activation according to posture change at 0 degrees of hip abduction

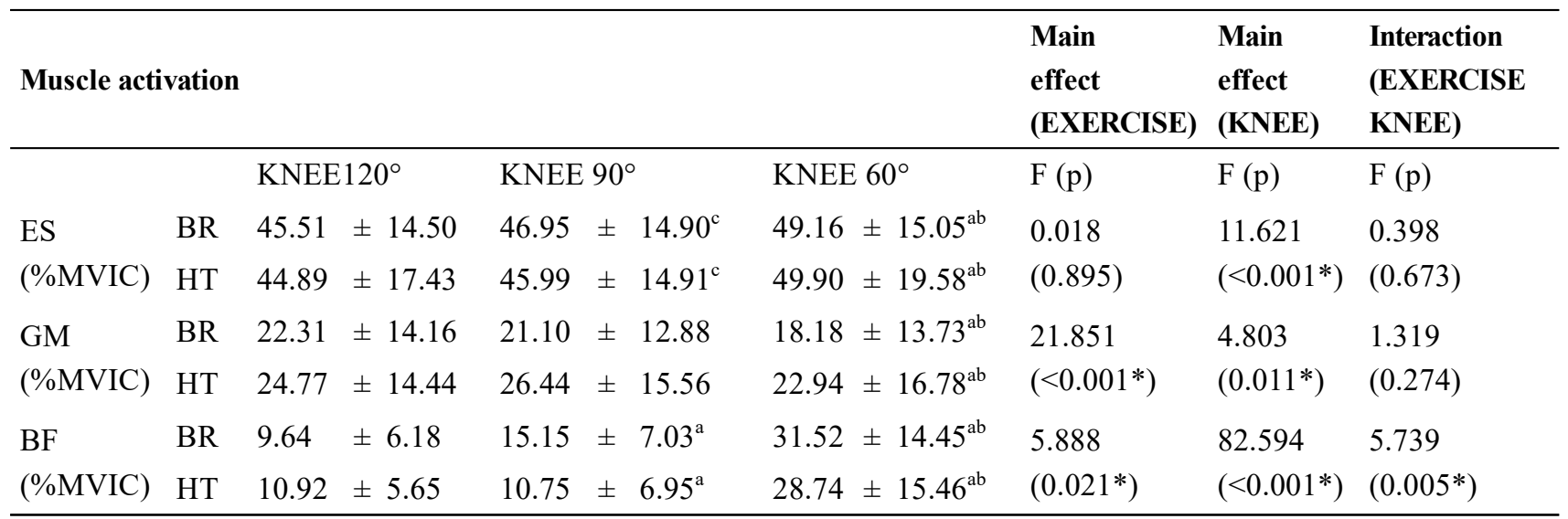

ES: Erector Spinae, GM: Gluteus Maximus, BF: Biceps Femoris, BR: Bridge Exercise, HT: Hip Thrust Exercise.

${ }^{\mathrm{a}}$ Significant difference with knee $120(\mathrm{p}<0.05)$.

${ }^{\mathrm{b}}$ Significant difference with knee $90(\mathrm{p}<0.05)$.

$* \mathrm{p}<0.05$

하게 크게 나타났다 $(\mathrm{p}<0.05)$,

대둔근의 근활성도고관절 $30^{\circ}$ 외전을 적용 시, 운동 종류 와 무릎 자세 변화의 주효과가 유의하였으나 $(\mathrm{F}=40.394, \mathrm{p}$ $<0.05 ; \mathrm{F}=6.023, \mathrm{p}<0.05)$ 운동 종류와 무릎 자세 변화 의 상호작용효과가 유의하지 않았다. 사후 분석 결과 근 활성도는 무릎 자세의 조건이 $120^{\circ}$ 굴곡에서 $90^{\circ}, 60^{\circ}$ 굴 곡 보다 크게 나타났다 $(\mathrm{p}<0.05)$.

\section{대퇴이두근}

대퇴이두근 근활성도고관절 $0^{\circ}$ 외전을 적용시 운동 종 류와 무릎 자세 변화의 주효과 그리고 운동 종류와 무릎 자세 변화의 상호작용 효과에도 유의하였다 $(\mathrm{F}=5.888, \mathrm{p}$ $<0.05 ; \mathrm{F}=82.594, \mathrm{p}<0.05 ; \mathrm{F}=5.739, \mathrm{p}<0.05)$. 사후 분 석 결과 근활성도는 고관절 $0^{\circ}$ 외전 적용 시 무릎 자세의 조건이 $60^{\circ}$ 굴곡에서 $120^{\circ}, 90^{\circ}$ 굴곡보다 유의하게 크게 나타났으며, $90^{\circ}$ 굴곡 자세는 $120^{\circ}$ 굴곡 자세보다 유의하 게 크게 나타났다 $(\mathrm{p}<0.05)$.

대퇴이두근 근활성도고관절 $30^{\circ}$ 외전을 적용 시 운동 종류와 무릎 자세 변화의 주효과 그리고 운동 종류와 무 릎 자세 변화의 상호작용 효과에도 유의하였다. $(\mathrm{F}=9.252$, $\mathrm{p}<0.05 ; \mathrm{F}=84.176, \mathrm{p}<0.05 ; \mathrm{F}=16.019, \mathrm{p}<0.05)$. 사후 분석 결과 근활성도는 고관절 $0^{\circ}$ 외전 적용 시 무릎 자세 의 조건이 $60^{\circ}$ 굴곡에서 $120^{\circ}, 90^{\circ}$ 굴곡보다 유의하게 크 게 나타났으며, $90^{\circ}$ 굴곡 자세는 $120^{\circ}$ 굴곡 자세보다 유 의하게 크게 나타났다 $(\mathrm{p}<0.05)$

\section{고찰}

본 연구에서는 정상 성인을 대상으로 교각 운동과 추력 운동 시 무릎 자세 변화가 체간 및 하지 근활성도의 변화 에 미치는 영향을 비교하고자 하였다. 척추 기립근은 고 관절 $30^{\circ}$ 외전을 적용 시 교각운동과 추력운동 차이에 따 라 유의한 차이를 나타내었으며 무릎 각도의 변화에 따라 유의한 차이를 나타내었다 $(\mathrm{p}<0.05)$. Yoon 등[11]은 일반 적인 교각 운동보다 한 다리로 수행하는 교각 운동이 척 추 기립근의 더 큰 근활성도를 나타내었다 이는 대표적인 체간근인 척추 기립근이 체간의 지지면에 따라 근활성도 가 달라지는 것을 알 수 있다. 이는 교각 운동과 추력 운 동 모두 고관절을 $30^{\circ}$ 외전하였을 때 대표적인 체간 안정 근인 척추 기립근이 외전한 고관절의 각도 만큼 체간의 균형을 잡기 위해 척추 기립근의 높은 근활성도를 보인 것이며, 무릎 각도를 $60^{\circ}$ 으로 굽혔을 때 높은 근활성도를 보이는 것으로 보아 추력 운동과 교각 운동 모두 지렛데 가 증가함에 따라 높은 근활성도를 나타낸 것을 알 수 있 으며, 고관절 외전 $30^{\circ}$ 에서 추력 운동이 교각 운동보다 더 높은 근활성도를 보인 것은 추력 운동이 교각 운동보 다 상지의지지면이 더 좁아진 상태에서 체간의 균형을 잡 기 위한 척추 기립근의 근 활성도가 높아진 것을 알 수 있다. 대둔근의 경우, 고관절 $0^{\circ}$ 와 $30^{\circ}$ 외전을 적용 시, 운동 종류와 무릎 자세 변화의 주효과가 유의하였다 $(\mathrm{p}$ $<0.05)$. Kang 등[10]은 교각 운동시 고관절 외전 각도 $0^{\circ}, 15,{ }^{\circ} 30^{\circ}$ 세 가지 각도 가운데 따른 대둔근과 슬괵근 간의 근전도를 비교 하였는데 이때 외전 $30^{\circ}$ 에서 대둔근 의 근활성도가 가장 높게 나타났으며, $0^{\circ}$ 에서 슬괵근의 
Table 2. Muscle activation according to posture change at 30 degrees of hip abduction

$(\mathrm{n}=33)$

\begin{tabular}{|c|c|c|c|c|c|c|c|}
\hline \multicolumn{5}{|c|}{ Muscle activation } & \multirow{2}{*}{$\begin{array}{l}\begin{array}{l}\text { Main } \\
\text { effect } \\
\text { (EXERCISE) }\end{array} \\
\mathrm{F}(\mathrm{p})\end{array}$} & \multirow{2}{*}{$\begin{array}{l}\begin{array}{l}\text { Main } \\
\text { effect } \\
\text { (KNEE) }\end{array} \\
\mathrm{F}(\mathrm{p})\end{array}$} & \multirow{2}{*}{$\begin{array}{l}\text { Interaction } \\
\text { (EXERCISE } \\
\text { KNEE) } \\
\mathrm{F}(\mathrm{p})\end{array}$} \\
\hline & & KNEE $120^{\circ}$ & KNEE $90^{\circ}$ & KNEE $60^{\circ}$ & & & \\
\hline ES & $\mathrm{BR}$ & $48.76 \pm 15.69$ & $48.19 \pm 15.94$ & $52.99 \pm 14.88^{\mathrm{ab}}$ & \multirow{2}{*}{$\begin{array}{l}5.45 \\
\left(0.026^{*}\right)\end{array}$} & \multirow{2}{*}{$\begin{array}{l}13.001 \\
\left(<0.001^{*}\right)\end{array}$} & \multirow{2}{*}{$\begin{array}{l}0.576 \\
(0.565)\end{array}$} \\
\hline (\%MVIC) & HT & $51.69 \pm 14.65$ & $52.98 \pm 16.59$ & $56.18 \pm 17.44^{\mathrm{ab}}$ & & & \\
\hline GM & $\mathrm{BR}$ & $29.77 \pm 20.26^{\mathrm{b}}$ & $23.97 \pm 16.47^{\mathrm{a}}$ & $25.45 \pm 18.13^{\mathrm{a}}$ & \multirow{2}{*}{$\begin{array}{l}40.394 \\
\left(<0.001^{*}\right)\end{array}$} & \multirow{2}{*}{$\begin{array}{l}6.023 \\
(0.004 *)\end{array}$} & \multirow{2}{*}{$\begin{array}{l}1.142 \\
(0.325)\end{array}$} \\
\hline (\%MVIC) & HT & $37.97 \pm 21.39^{b}$ & $35.52 \pm 20.45^{\mathrm{a}}$ & $35.97 \pm 19.02^{\mathrm{a}}$ & & & \\
\hline $\mathrm{BF}$ & $\mathrm{BR}$ & $8.94 \pm 4.58$ & $17.05 \pm 10.31^{\mathrm{a}}$ & $30.41 \pm 13.98^{\mathrm{ab}}$ & \multirow{2}{*}{$\begin{array}{l}9.252 \\
\left(0.005^{*}\right)\end{array}$} & \multirow{2}{*}{$\begin{array}{l}84.176 \\
(<0.001 *)\end{array}$} & \multirow{2}{*}{$\begin{array}{l}16.019 \\
(<0.001 *)\end{array}$} \\
\hline (\%MVIC) & HT & $11.15 \pm 6.08$ & $11.23 \pm 7.86^{\mathrm{a}}$ & $24.17 \pm 13.68^{\mathrm{ab}}$ & & & \\
\hline
\end{tabular}

ES: Erector Spinae, GM: Gluteus Maximus, BF: Biceps Femoris, BR: Bridge Exercise, HT: Hip Thrust Exercise.

${ }^{\text {a }}$ Significant difference with knee $120(\mathrm{p}<0.05)$.

${ }^{\mathrm{b}}$ Significant difference with knee $90(\mathrm{p}<0.05)$.

$* \mathrm{p}<0.05$

근활성도가 가장 높게 나타났는데 이는 대둔근 섬유 방향 과도 관련이 있다. $\mathrm{Kim}$ 등[12]은 대둔근이 외회전 $25^{\circ}$ 시 가장 높은 근활성도를 나타내었는데 이는 근섬유 배열 방향이 근수축에 기여한다는 것을 알 수 있었고 배열과 근 수축 방향이 일치할 때 더 큰 효과를 나타내었다. Contreras 등[7]은 고관절 위에 바벨을 올려 수행하는 기 본 추력 운동, 고관절 위에 바벨이 아닌 저항 밴드를 끼워 수행하는 추력운동 그리고 고관절 위에 바벨을 올린 상태 로 고관절을 후방 굴곡 시켜 수행하는 추력 운동을 수행 하여 대둔근과 슬괵근근활성도를 측정하여 가장 높은 근 활성도를 비교하였는데 저항 밴드를 끼워 수행한 추력 운 동보다는 바벨을 올려 수행한 추력 운동이 모든 면에서 크게 차이를 보였다. 이는 지렛대의 길이 차이에 의한 결 과라고 보고하였다. Anderson 등[3]은 추력 운동과 데드 리프트간의 운동을 비교하였는데 추력 운동은 대둔근에서 가장 높은 근활성도를, 데드리프트 운동에서는 대퇴이두 근에서 가장 높은 근활성도를 나타내었다. 이는 추력 운 동이 데드리프트, 스쿼트보다 대둔근의 근활성도가 높은 것은 동작의 끝범위가 크기 때문이다[3]. 대둔근은 둔근 가운데 가장 크고 표면에 위치한 근육으로 근섬유방향은 아래쪽과 바깥쪽으로 비스듬히 향하고 있으며 대퇴부의 신전과 외회전을 보조하는 기능을 갖고 있으며 상부 섬유 는 외전에 일차적으로 작용하며 하부 섬유는 대퇴부를 굴 곡한 상태에서 강한 저항에 반하여 외전하는 기능을 갖고 있는 근육이다. 본 연구에서는 고관절 외전 $30^{\circ}$ 시 교각 운동과 추력 운동 모두 척추기립근과 대둔근에서근활성도 가 유의하게 크게 나타났으며 $(\mathrm{p}<0.05)$, 대퇴이두근에서 는 모든 각도에서 차이를 보였다. 이는 대둔근의 근섬유
의 방향과도 관련이 있으며 배열과 근 수축 방향이 일치 할 때 더 큰 효과를 나타냄을 알 수 있었다[10,12].대둔근 의 굴곡 각도가 클수록 대둔근의 낮은 근활성도를 보이며 대둔근의 신전 마지막 동작 범위에서 최대치의 근활성도 를 나타낸다(Worrell 2001). 이를 통해 교각 운동과 추력 운동의 차이는 고관절의 가동 운동 범위의 차이에서 나타 나는 것이라 사료된다. 따라서 추력 운동시 대둔근을 고 립시켜 자극시키고자 할 때에는 무릎의 각도를 체간과 밀 착시켜 대퇴이두근의 활성화를 최소화 시킨 상태에서 대 둔근의 근섬유 방향에 맞게 $30^{\circ}$ 외전 시킨 상태로 고관절 의 보다 넓은 가동 범위를 활용하여 신전시 마지막 동작 에서 최대치 근활성도를 보일 수 있는 추력 운동이 교각 운동보다 대둔근의근활성도를 더 효과적으로 유발할 수 있다고 사료된다. 대퇴이두근의 경우 고관절 $0^{\circ}$ 와 $30^{\circ}$ 외 전을 적용시 운동 종류와 무릎 자세 변화의 주효과 그리 고 운동 종류와 무릎 자세 변화의 상호작용 효과에도 유 의하였다 $(\mathrm{p}<0.05)$. 교각 운동과 추력 운동 모두 무릎 각 도 굴곡에 따른 근활성도의 변화는 무릎 굴곡 각도가 체 간과 가까워지는 $120^{\circ}$ 로 굽혔을 때 대퇴이두근의 근활성 도가 최소화되었고 $60^{\circ}$ 에서 가장 높이 기록된 것은 척추 기립근과 대둔근에 비해 대퇴이두근이 무릎과 가장 가깝 게 위치하고 있으며 무릎 굴곡 동작에 직접적인 관여를 하여 나타나는 현상으로 사료된다.

Reiman 등[2]은 교각 운동시 무릎 굴곡 각도가 $90^{\circ}$ 인 자세일 때 슬괵근의 역할을 최소화하고 대둔근 강화에 집 중할 수 있다고 하였다. Lehecka 등[5]과 Hirose 등[6]은 또한 교각 운동이 무릎 굴곡의 각도를 $0^{\circ}, 60^{\circ}, 90^{\circ}, 120^{\circ}$ 의 각도로 다르게 설정하여 수행하였는데 무릎 굴곡 각도 
가 좁아질수록 대둔근의 활성도가 높아지고 굴곡 각도가 넓어질수록 대퇴이두근의 근 활성도가 높게 나타났다. 이 는 근길이가 증가함에 따른 근활성도 또한 증가됨을 알 수 있었으며 닫힌 사슬에서의 교각 운동에서의 무릎 굴곡 각도에 따른 대퇴이두근과 대둔근의 상관관계를 알 수 있 었으며, 교각 운동이 무릎 굴곡 각도와는 무관하게 대둔 근 강화 운동에는 효과적이지 않을 수도 있으나 대둔근 강화를 위해서는 슬괵근을 최소화 하는 무릎 굴곡 각도를 체간과 가까이 하기에 달려있다고 하였다[6]. 또한 기존의 교각 운동의 연구 결과뿐만 아니라 이번 연구에서의 추력 운동 또한 고관절 외전 $30^{\circ}$ 시 무릎 굴곡 각도가 $120^{\circ}$ 경 우 모두 대둔근의 근활성도가 높게 나온 반면 대퇴 이두 근의 근활성도는 가장 낮게 나온 것으로 보아 대둔근은 무릎이 체간과 가까워질수록 더 크게 사용되는 것을 알 수 있었다. 따라서 본 연구는 고관절 및 무릎 각도 변화를 통해 체간과 하지 근육들에 외적 부하를 적용하여야 할 때 효과적인 훈련 자료가 될 수 있을 것이라 사료되며 특 정 근육에 대한 강화 운동 시 목표로 하는 운동 각도의 선택적 지표로 활용될 수 있을 것으로 사료된다. 이 연구 에서는 대둔근과 척추기립근의 경우 교각 운동보다 더 큰 지렛대의 길이와 고관절 가동 범위를 요하는 추력 운동에 서 근육의 근활성도가 증가됨을 알 수 있었으며, 대퇴이 두근의 경우 고관절의 가동 범위와는 무관하게 무릎 굴곡 각도가 더 작아질수록 더 큰 근활성도를 나타냄을 알 수 있었다. 따라서 추력 운동시 대둔근을 고립시켜 자극 시 키고자 할 때에는 무릎의 각도를 체간과 밀착시켜 대퇴이 두근의 활성화를 최소화 시킨 상태에서 대둔근의 근섬유 방향에 맞게 $30^{\circ}$ 외전 시킨 상태로 고관절의 보다 넓은 가동 범위를 활용하여 신전시 마지막 동작에서 최대치 근 활성도를 보일 수 있는 추력 운동이 교각 운동보다 더 많 은 근력 향상을 요하는 대둔근의 강화를 더 효과적으로 유발할 수 있다고 사료된다.

\section{결론}

본 연구의 목적인 정상인을 대상으로 교각 운동과 추력 운동의 무릎 굴곡 각도 변화에 따른 체간 및 하지 근육간 의근활성도를 알아보고 향후 운동 처방의 기초 자료를 제 시하고자 하였다. 본 연구에서는 교각 운동보다 추력 운 동에서 대둔근과 척추기립근의 근활성도가 증가하는 것을 알 수 있었다. 또한 추력 운동 역시 교각 운동과 마찬가지 로 고관절 외전 $30^{\circ}$ 에서 대둔근과 척추기립근의 근활성 도 증가하는 것으로 나타났다. 무릎 굴곡의 각도가 $60^{\circ}$ 에서의 교각 운동이 추력 운동보다 대퇴이두근의 근활성 도가 가장 낮게 나타났다. 또한 본 연구에서 추력 운동 시 대둔근과척추기립근 같은 주된 작용근의근활성화에효과적
이였으며 무릎 굴곡 각도 변화는 대둔근의근활성화에효과 적이였다. 따라서 본 연구는 특정 근육에 대한 둔부 강화 운동 시 목표로 하는 운동 각도의 선택적 지표로 활용될 수 있을 것으로 사료된다.

\section{이해충돌}

본 연구의 저자들은 연구, 저작권 및 출판과 관련하여 잠재적인 이해충돌이 없음을 선언합니다.

\section{참고문헌}

1. Distefano LJ, Blackburn JT, Marshall SW, Padua DA. Gluteal muscle activation during common therapeutic exercises. J Orthop Sports Phys Ther. 2009;39:532-40.

2. Reiman MP, Bolgla LA, Loudon JK. A literature review of studies evaluating gluteus maximus and gluteus medius activation during rehabilitation exercises. Physiother Theory Pract. 2012;28:257-68.

3. Andersen V, Fimland MS, Mo, DA, Iversen VM, Vederhus T, Hellebø LR. et al. Electromyographic comparison of barbell deadlift, hex bar deadlift, and hip thrust exercises: A cross-over study. J Strength Cond Res. 2018;32:587-93.

4. Sakamoto AC, Teixeira-Salmela LF, de Paula FR, de MoraisFaria, CD, Guimaraes CQ. Muscular activation patterns during active prone hip extension exercises. J ElectromyogrKinesiol. 2009;19:105-12.

5. Lehecka B, Edwards M, Haverkamp R, Martin L, Porter K, Thach $\mathrm{K}$ et al. Building a better gluteal bridge: electromyographic analysis of hip muscle activity during modified single-leg bridges. Int $\mathrm{J}$ Sports Phys Ther. 2017;12:543-9.

6. Hirose $N$, Tsuruike $M$. Differences in the Electromyographic Activity of the Hamstring, Gluteus Maximus, and Erector Spinae Muscles in a Variety of Kinetic Changes. J Strength Cond Res. 2018;32:3357-63.

7. Contreras B, Vigotsky AD, Schoenfeld BJ, Beardsley C, Cronin J. A comparison of gluteus maximus, biceps femoris, and vastus lateralis electromyography amplitude for the barbell, band, and American hip thrust variations. J Applbiomech. 2016;32:254-60.

8. Worrell TW, Karst G, Adamczyk D, Moore R, 
Stanley C, Steimel B, et al. Influence of joint position on electromyographic and torque generation during maximal voluntary isometric contractions of the hamstrings and gluteus maximus muscles. J Orthop Sports Phys Ther. 2001;31:730-40.

9. Ayotte NW, Stetts DM, Keenan G, Greenway EH. Electromyographical analysis of selected lower extremity muscles during 5 unilateral weight-bearing exercises. J Orthop Sports Phys Ther. 2007;37:48-55.

10. Kang SY, Jeon HS, Kwon O, Cynn HS, Choi B. Activation of the gluteus maximus and hamstring muscles during prone hip extension with knee flexion in three hip abduction positions. Man Ther. 2013;18:303-7.

11. Yoon JO, Kang MH, Kim JS, Oh JS. Effect of modified bridge exercise on trunk muscle activity in healthy adults: a cross sectional study. Braz J Phys Ther. 2018;22:161-7.

12. Kim CM, Kong YS, Hwang YT, Park, JW. The effect of the trunk and gluteus maximus muscle activities according to support surface and hip joint rotation during bridge exercise. J Phys Ther Sci. 2018;30:943-7. 